\title{
Rośliny naczyniowe obcego pochodzenia zadomowione w lasach Polski
}

\author{
WŁadysŁaw Danielewicz, Blanka Wiatrowska, Zygmunt DaJdok \\ i BARBARA TOKARSKA-GUZIK
}

\begin{abstract}
Danielewicz, W., Wiatrowska, B., Dajdok, Z. And TokARska-GuZiK, B. 2020. Alien vascular plants established in forests of Poland. Fragmenta Floristica et Geobotanica Polonica 27(2): 451-471. Kraków. e-ISSN 2449-8890, ISSN 1640-629X.

ABSTRACT: The forest environment is considered to be more resistant to penetration by alien plant species than other terrestrial environments, which generally are significantly modified by humans. A major environmental threat to vegetation is posed by alien species that are capable of spontaneous expansion in natural or semi-natural communities, and above all in forests. This paper presents a naturalization scale of alien vascular plants in forests of Poland, based on knowledge of species classified as naturalized elements of the Polish flora. Using the research results and observations of other authors, as well as literature data, a list of 180 taxa of such plants was compiled. The classification uses the following categories: life form, systematic affiliation, and origin or status in the Polish flora. The analysis revealed that not all of the considered alien species showed an ability to penetrate forest communities and that only a few of them have developed stable populations in the best-preserved natural and semi-natural phytocoenoses. About $20 \%$ of the anthropophytes found in forest communities strongly affect the composition and structure of the forest phytocoenoses.
\end{abstract}

KEY WORDS: alien flora, forest environment, Poland, species diversity

W. Danielewicz (autor korespondencyjny), B. Wiatrowska, Katedra Botaniki Leśnej, Uniwersytet Przyrodniczy w Poznaniu, ul. Wojska Polskiego 71 D, 60-625 Poznań, Polska;

e-mail: danw@up.poznan.pl

Z. Dajdok, Instytut Biologii Środowiskowej, Uniwersytet Wrocławski, ul. Kanonia 6/8, 50-328 Wrocław, Polska

B. Tokarska-Guzik, Katedra Botaniki i Ochrony Przyrody, Uniwersytet Ślaski, ul. Jagiellońska 28, 40-032 Katowice, Polska

\section{WSTEP}

Flora naczyniowa Polski liczy około 2500 gatunków rodzimych (MiReK i in. 2002; ZAJĄC \& ZAJĄC 2001, 2003). Oprócz nich do stałych składników flory naszego kraju zalicza się również grupę roślin obcego pochodzenia (tzw. antropofitów, czyli obcych roślin synantropijnych), które są trwale zadomowione, tzn. po celowej introdukcji lub zawleczeniu mają zdolność do tworzenia samoutrzymujących się populacji wtórnych. Ze względu na czas przybycia wyróżnia się wśród nich dwie grupy gatunków: archeofity, o których wiadomo, 
że pojawiły się przed końcem XV w. oraz kenofity, przybyłe po okresie wielkich odkryć geograficznych, umownie od daty odkrycia Ameryki (KoRnAŚ 1981).

W pierwszym wydaniu opracowania pt. „Krytyczna lista roślin naczyniowych w Polsce” (MireK i in. 1995) uwzględniono 345 trwale zadomowionych antropofitów. Ich liczba zwiększyła się w drugim wydaniu wspomnianej pracy (MIREK i in. 2002) do 439, a w publikacji TOKARSKIEJ-GuZIK i in. (2012) wymieniono ich 527 (w tym 157 archeofitów i 370 kenofitów). Z krajów sąsiednich, w których przeprowadzono podobne analizy flor, podano następujące liczby obcych trwale zadomowionych taksonów: z Niemiec - 645 (LAMBDON i in. 2008), z Czech - 469 (PyŠEK i in. 2012) i 464 (DANIHELKa 2012), ze Słowacji - 373 (MEDWECKÁ i in. 2012). Podane liczby dotyczą gatunków zadomowionych na siedliskach i w zbiorowiskach roślinnych o różnej genezie i stopniu przekształcenia - zarówno naturalnych, jak i antropogenicznych.

Środowisko leśne jest uważane za bardziej odporne na wnikanie gatunków obcych niż inne ekosystemy lądowe (GAZDA 2013), które są na ogół w znacznie większym stopniu zmienione przez człowieka. Z przyrodniczego punktu widzenia największe zagrożenie dla rodzimej szaty roślinnej stwarzają te gatunki obce, które są zdolne do samorzutnej ekspansji na siedliskach i w zbiorowiskach naturalnych lub zbliżonych do naturalnych, a więc przede wszystkim w lasach. Problem ten był u nas dostrzegany od dawna, jednak w ostatnich latach nabrał szczególnego znaczenia w związku z włączeniem do krajowego systemu ochrony przyrody obszarów Natura 2000, z których znaczna część znajduje się na terenach leśnych, zajmując 2,89 mln ha czyli 38\% powierzchni terenów administrowanych przez Państwowe Gospodarstwo Leśne Lasy Państwowe (PGL LP) (MiLEwski 2018).

Problematyką klasyfikacji roślin synantropijnych zajmowało się wielu autorów, a pierwsze propozycje w tym zakresie, przyjęte i zmodyfikowane między innymi w polskim piśmiennictwie, pochodzą z początków XX w. Od tego czasu literatura dotycząca antropogenicznych przemian flory została poszerzona o liczne koncepcje podziału antropofitów na podstawie różnych kryteriów, co doprowadziło do znacznego wzbogacenia terminologii specjalistycznej, nie zawsze spójnej i dlatego wymagającej uporządkowania (SUDNIK-WóJCIKOwsKA \& KoźNIEWSKA 1988; RICHARDSON i in. 2000; PYŠEK i in. 2004; TOKARSKA-GUZIK i in. 2012). Ostatnio coraz powszechniej akceptowana jest propozycja RICHARDSONA i in. (2000), podziału obcych roślin na: gatunki niezadomowione (casual alien plants) i zadomowione (naturalized plants), a następnie podział drugiej z wymienionych grup na nieinwazyjne (not invasive) oraz inwazyjne (invasive plants). W grupie roślin inwazyjnych wyróżnia się gatunki niepowodujące szkód (not harmful species), chwasty (weeds) oraz gatunki zmieniające charakter i strukturę ekosystemów (transformers). Według cytowanej propozycji (RICHARDSON i in. 2000) gatunki zadomowione różnią się od niezadomowionych tym, że mają zdolność do stałego (niesporadycznego) rozmnażania się i wytwarzania wielu trwałych generacji wtórnych, których istnienie jest niezależne od bezpośredniej ingerencji człowieka. Te spośród gatunków zadomowionych, które wytwarzają żywotne potomstwo w dużej ilości i rozprzestrzeniają się na znaczną odległość od roślin macierzystych zaliczane są do obcych gatunków inwazyjnych.

Celem niniejszej pracy jest przedstawienie skali zjawiska naturalizacji obcych roślin naczyniowych w lasach Polski na podstawie wiedzy o gatunkach, które zgodnie z kryteriami RichARDSONA i in. (2000) można zaliczyć do elementów flory obcego pochodzenia zadomowionych na obszarze Polski. 


\section{MATERIAE I METODY}

Głównym źródłem informacji o występowaniu i zadomawianiu się roślin obcego pochodzenia w lasach były materiały od wielu lat gromadzone przez autorów w trakcie badań terenowych prowadzonych na terenach leśnych, a także wiadomości zaczerpnięte z publikacji geobotanicznych, z których najważniejsze, jakie ukazały się do 2012 r., zostały wymienione w opracowaniu TOKARSKIEJ-GuzIK i in. (2012). W analizach przeprowadzonych na potrzeby niniejszego artykułu wykorzystano prace dotyczące naturalizacji introdukowanych drzew i krzewów (np. CHYLARECKI 1963, 2004; BELlon i in. 1977; Król 1988, 2000; DANIELEWICZ \& MALIŃSKI 1996, 1997, 2003, 2004; AdAMOWSKi i in. 2002; OBIDZIŃSKI i in. 2003; PURCel 2009; DajdoK i in. 2011; Gazda \& Augustynowicz 2012; Danielewicz \& Wiatrowska 2013; Danielewicz i in. 2014; WiATROWSKA \& DANIELEWICZ 2016), monografie niektórych rodzajów uważanych za trudne pod względem systematycznym, np. róż (ZIELIŃSKI 1987) czy malin i jeżyn (ZIELIŃSKI 2004), a także liczne opracowania z zakresu fitogeografii (flory o charakterze regionalnym i lokalnym oraz artykuły i notatki florystyczne), w których znajdują się wiadomości o stanowiskach obcych roślin synantropijnych zadomowionych w lasach (np. SzUlCZEWSKI 1963; ŻUKOWSKI i in. 1995; PIOTROWSKA i in. 1997; ZAJĄC \& ZająC 2001; TOKARSKA-GUZIK 2005; DAJDOK \& PAWLACZYK 2009; PIÓRECKI 2013).

Zgromadzone w ten sposób dane, po zweryfikowaniu w terenie kilku wątpliwych przypadków, posłużyły do sporządzenia listy antropofitów zadomowionych w warunkach środowiska leśnego, w różnym stopniu przekształconego, jednak bez obiektów urządzonej i pielęgnowanej zieleni, jak ogrody, arboreta, cmentarze itp. Nie uwzględniono taksonów o dyskusyjnym statusie w krajowej florze, do których zaliczane są: Quercus pubescens, Sorbus intermedia czy Ligustrum vulgare (MireK i in. 2002), a także gatunków rodzimych w jednych regionach naszego kraju, lecz obcych w innych. Międzygatunkowe mieszańce topoli potraktowano jako dwa zbiorowe taksony - topole euroamerykańskie (Populus $\times$ canadensis Moench.) oraz mieszańce topoli balsamicznych (m.in. $P$. 'NE 42', $P$. 'NE 49').

Zróżnicowanie grupy obcych gatunków roślin zadomowionych w lasach scharakteryzowano na podstawie liczby gatunków zakwalifikowanych do następujących kategorii: (1) forma życiowa (drzewo, krzew, bylina, roślina roczna lub dwuletnia, pnącze); (2) przynależność systematyczna do rodziny za opracowaniem MiRKA i in. (2002); (3) pochodzenie (kontynent lub takson znany tylko z uprawy); (4) status we florze Polski (archeofit, kenofit) według publikacji ToKARSKIEJ-GuzIK i in. (2012); (5) najczęstsza geneza leśnych stanowisk (introdukcja na skalę gospodarczą, introdukcja eksperymentalna, introdukcja okazjonalna, zawleczenie, migracja z zewnątrz) na podstawie badań własnych i przeglądu wielu różnych źródeł publikowanych oraz materiałów niepublikowanych; (6) częstość występowania w Polsce (liczba stanowisk według skali: pojedyncze, kilka i kilkanaście, kilkadziesiąt, setki, tysiące); (7) tendencje dynamiczne (zmiany liczby stanowisk $\mathrm{w}$ ostatnich dziesięcioleciach: spadek, brak wyraźnych zmian, nieznaczny wzrost, wyraźny wzrost, duży wzrost), na podstawie danych z publikacji ZARZYCKIEGO i in. (2002) oraz materiałów własnych; $(8)$ udział w zbiorowiskach roślinnych o różnym stopniu przekształcenia (leśne zbiorowiska naturalne, leśne zbiorowiska zastępcze, zbiorowiska obrzeży lasów, zbiorowiska porębowe i enklawy śródleśne, zbiorowiska na siedliskach antropogenicznych) według badań własnych i przeglądu licznych publikacji geobotanicznych; (9) wpływ na rodzime składniki fitocenoz i leśne zbiorowiska roślinne (wzbogacający skład gatunkowy, wyrównawczy i substytutywny - gatunek obcy zajmujący miejsce niewystępującego gatunku rodzimego, redukcyjny - gatunek obcy wypierający gatunek rodzimy, edyfikacyjny - gatunek obcy opanowujący i przekształcający strukturę zbiorowiska), według zmodyfikowanej koncepcji FALIŃSKIEGO $(1968,2004)$.

\section{WYNIKI}

Krajowa lista obcych roślin naczyniowych zadomowionych w środowisku leśnym obejmuje 180 gatunków (Tab. 1), czyli około 1/3 taksonów zaliczanych do kategorii antropofitów w całej Polsce i około 5,2\% naszej ogólnej flory. Wśród nich jest 100 gatunków roślin drzewiastych (41 - drzew, 59 - krzewów łącznie z 5 pnączami i 1 krzewinką) oraz 80 gatunków 


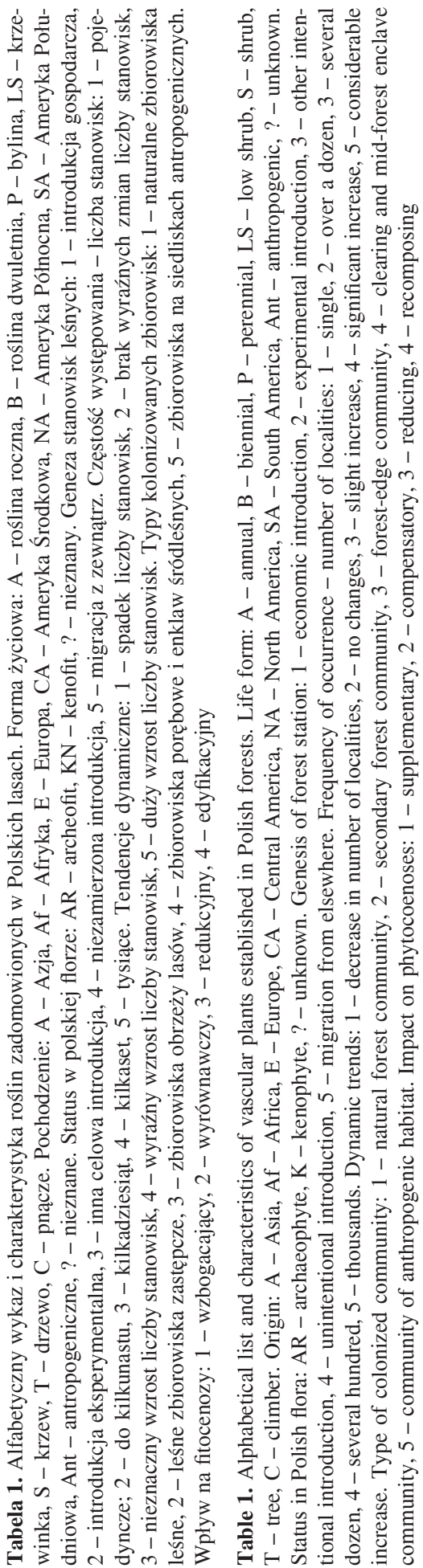

\begin{tabular}{|c|c|c|}
\hline 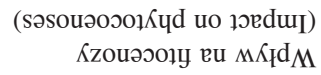 & 으 & $+\rightarrow-t-T-4 \mathrm{n} t+$ \\
\hline 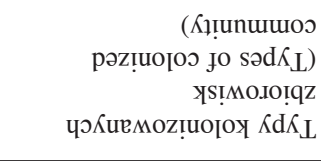 & $a$ & 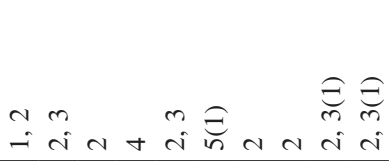 \\
\hline 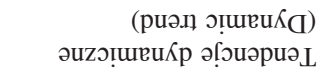 & $\infty$ & $n m-N m \sim N n m$ \\
\hline 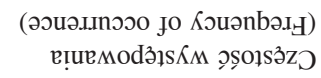 & $r$ & $n N-n+t m n m+$ \\
\hline 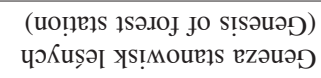 & 0 & $n m-n-m+-\rightarrow-$ \\
\hline 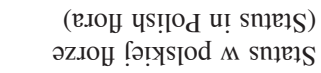 & in & 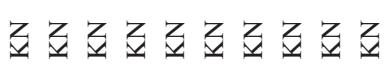 \\
\hline 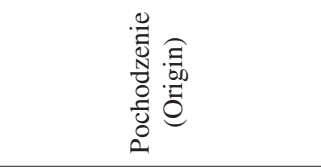 & $\nabla$ & 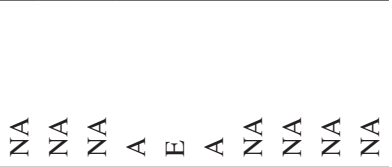 \\
\hline 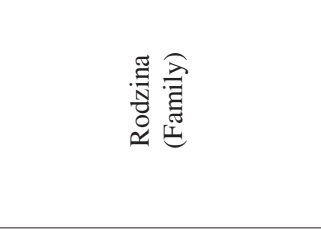 & $m$ & 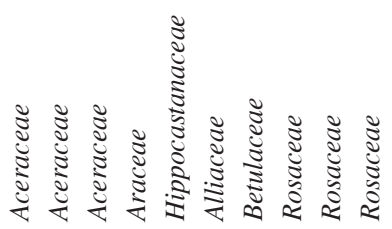 \\
\hline 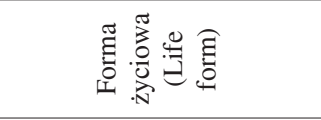 & $\mathrm{N}$ & 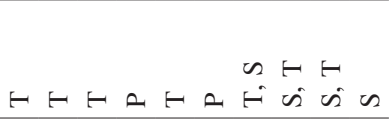 \\
\hline 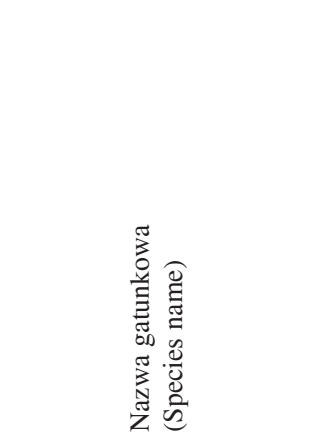 & - & 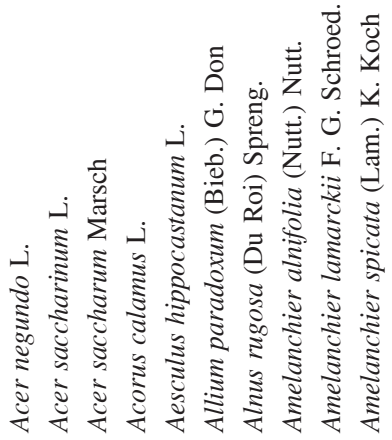 \\
\hline
\end{tabular}




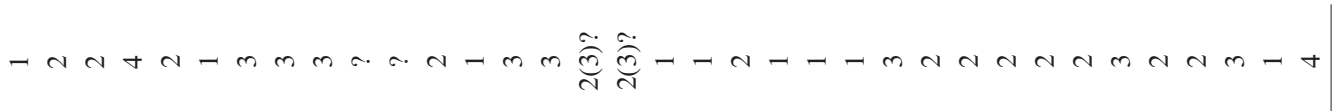

t

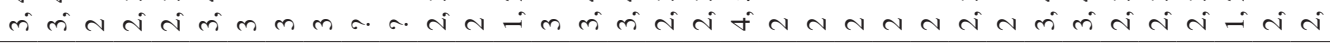

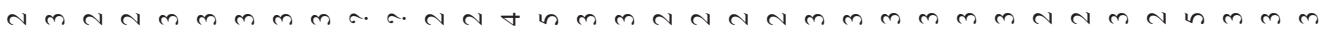

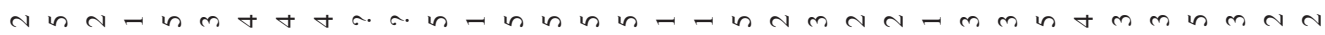

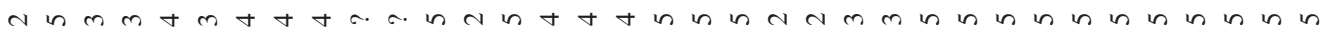

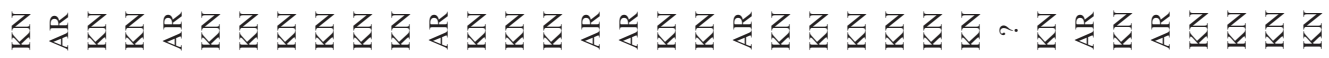

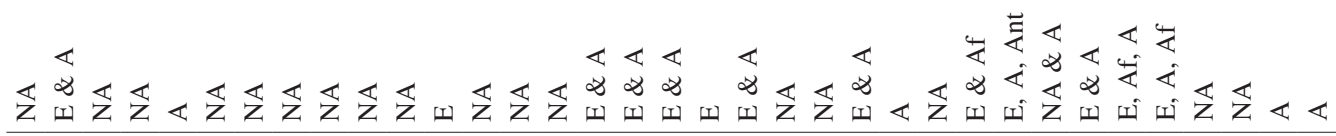

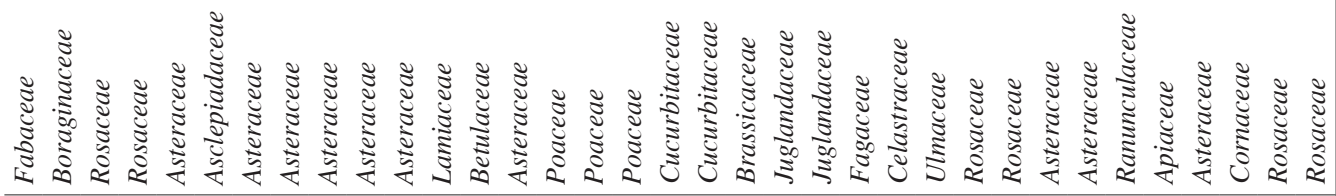

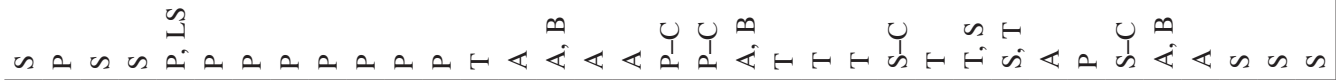

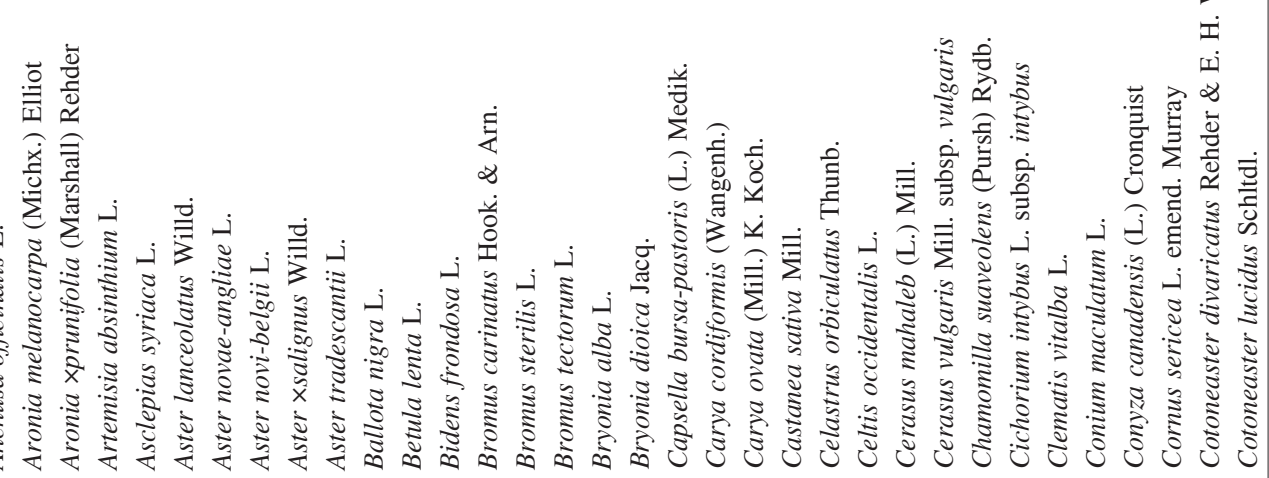




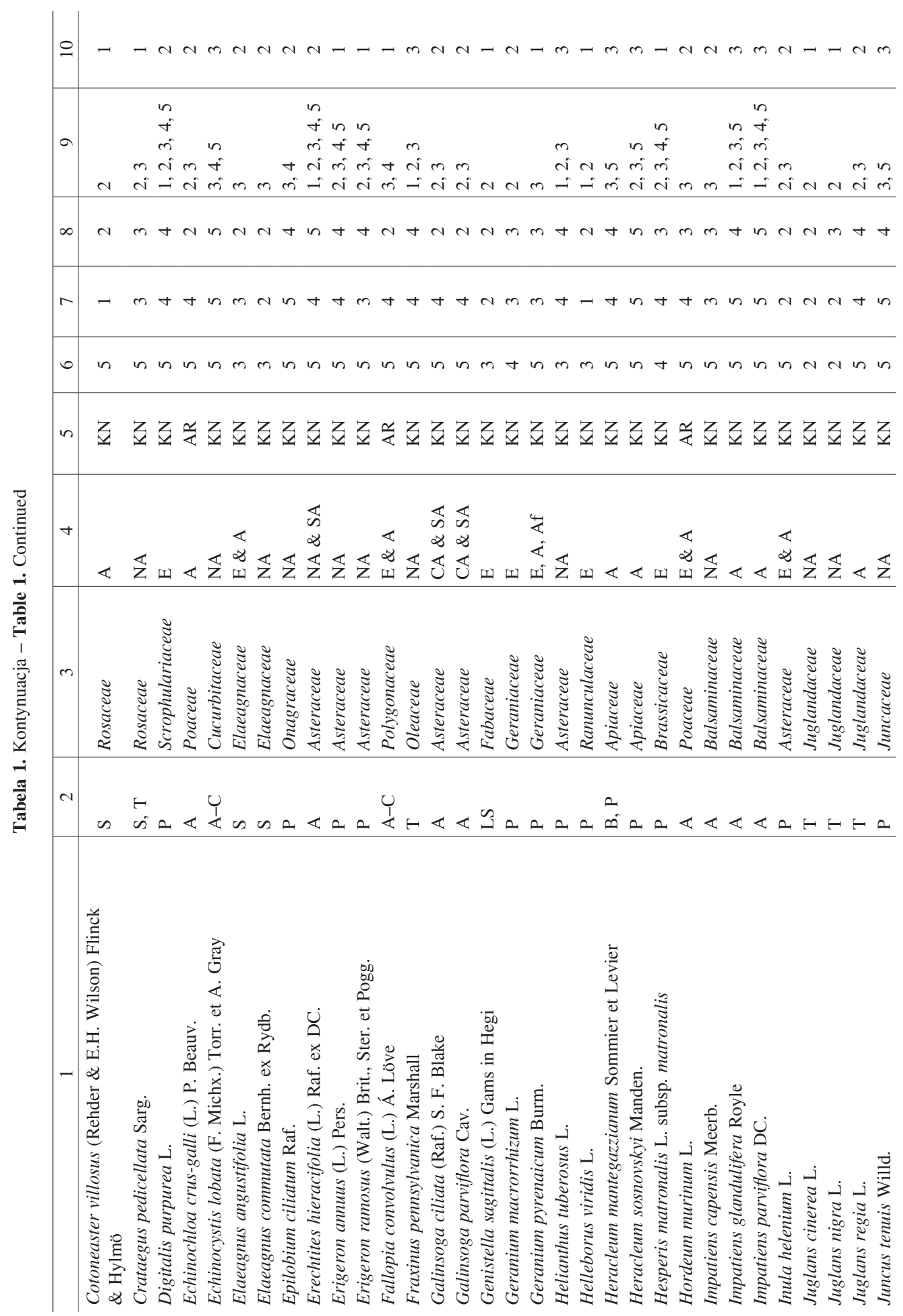




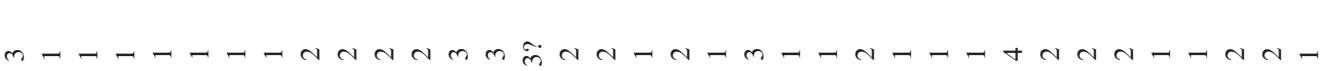

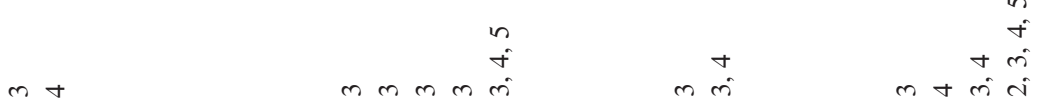

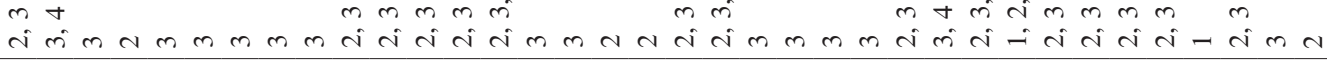

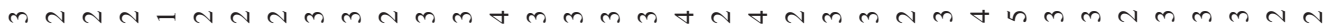

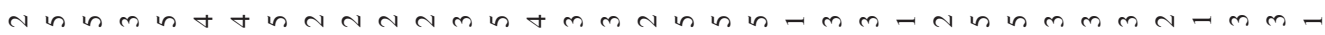

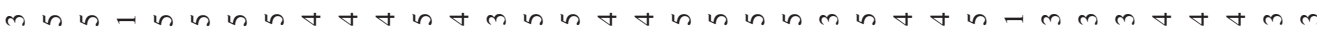

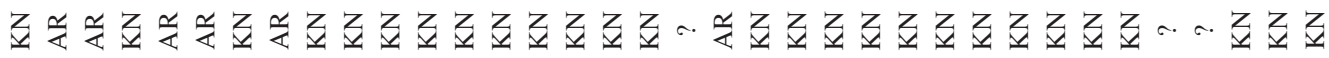

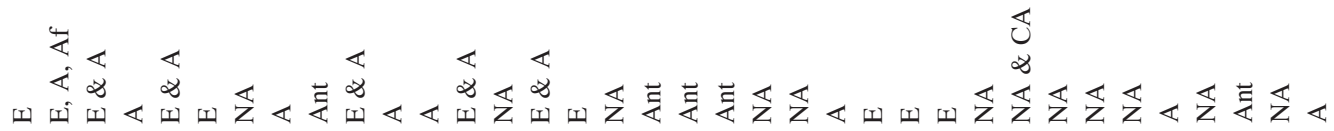

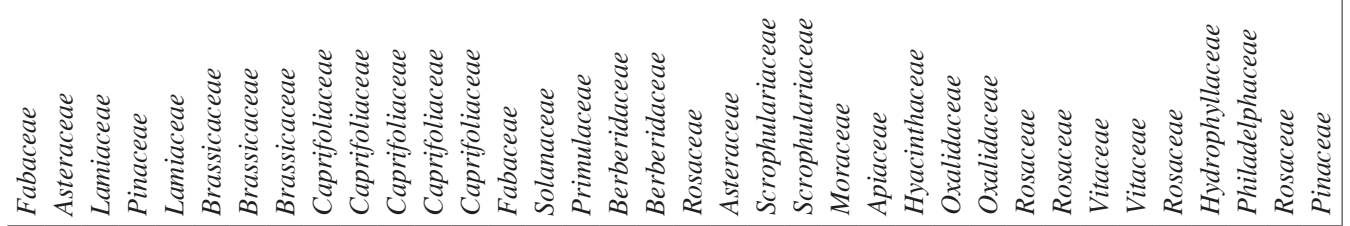

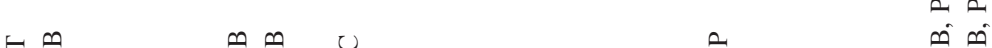
H̊

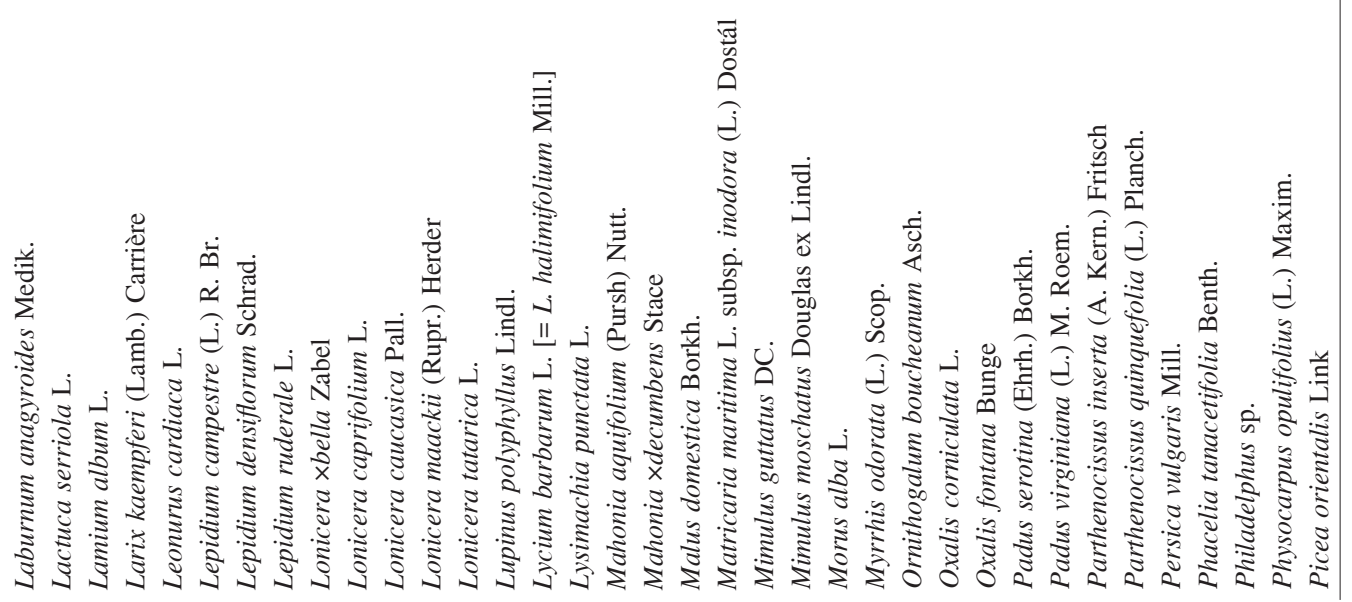




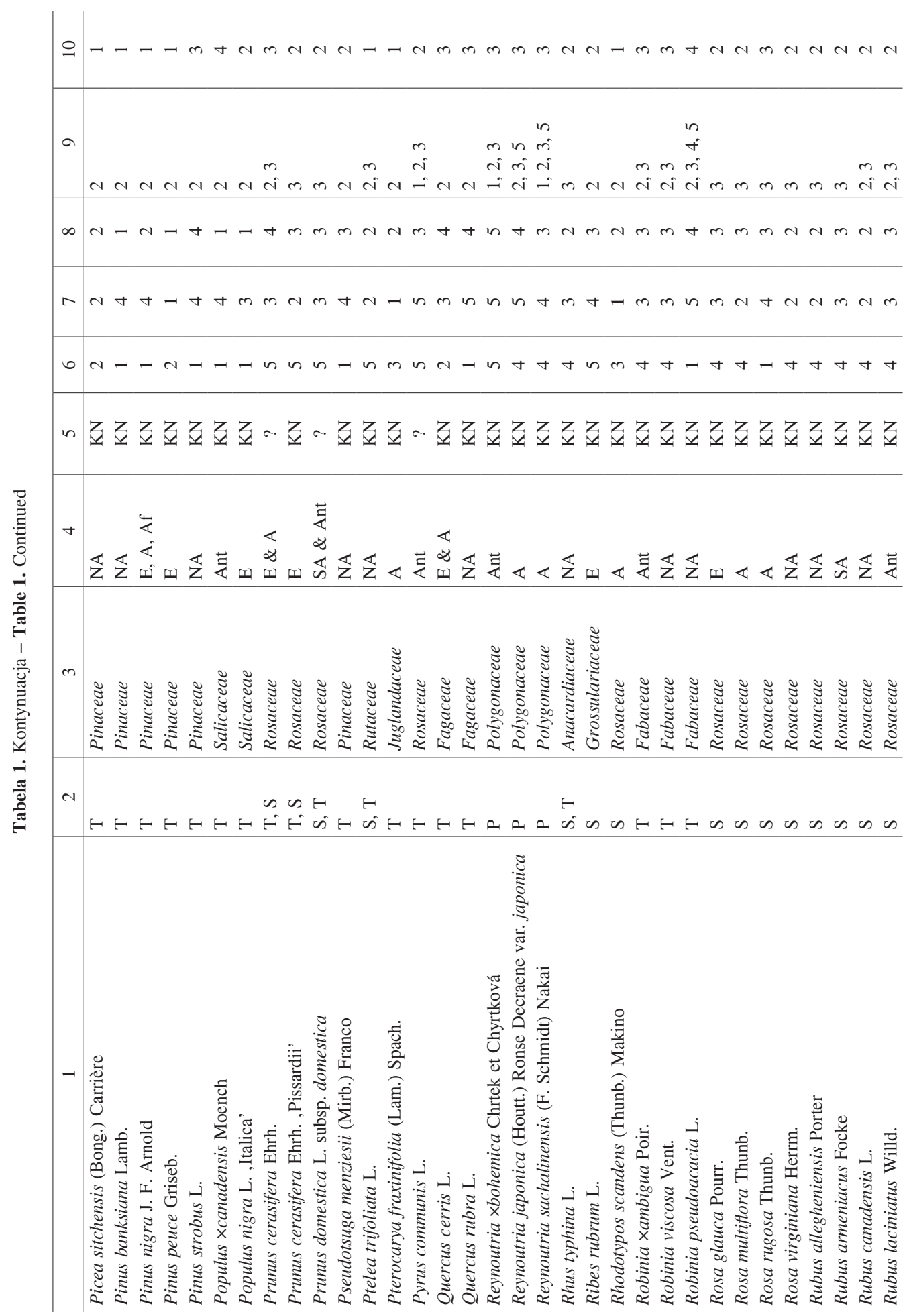




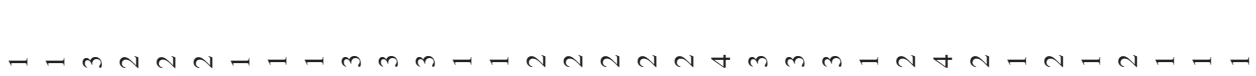

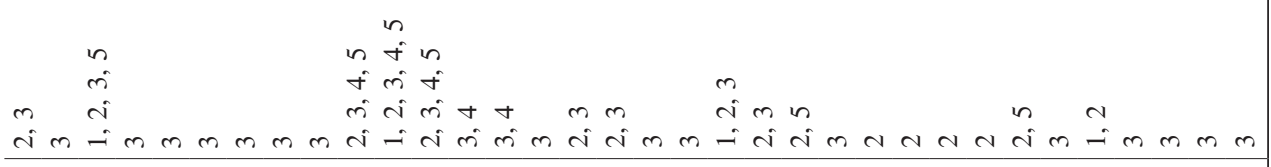

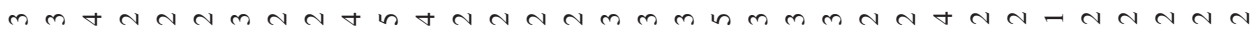

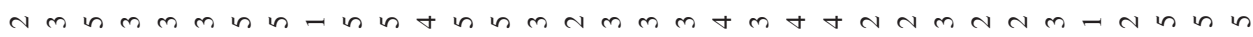

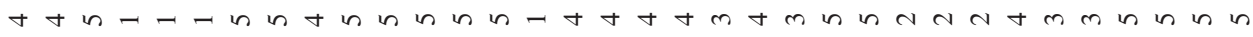

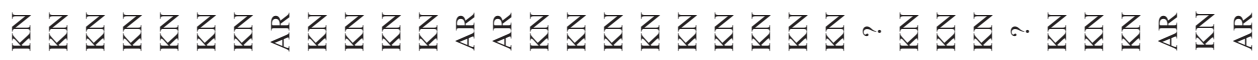

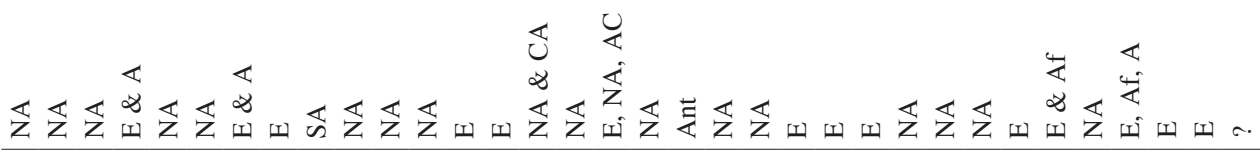

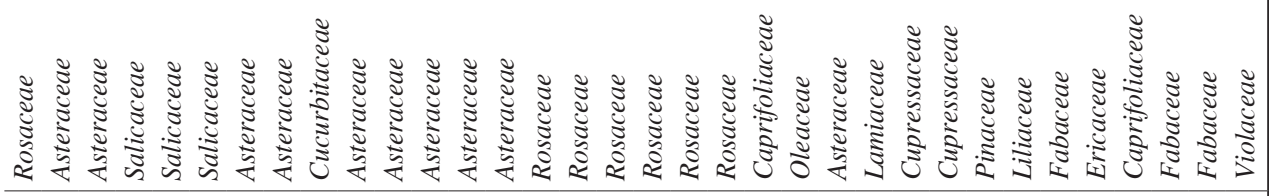

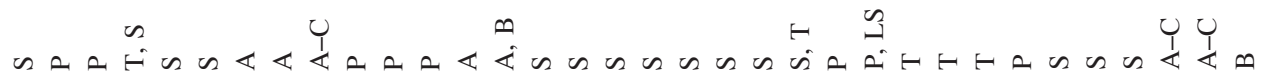

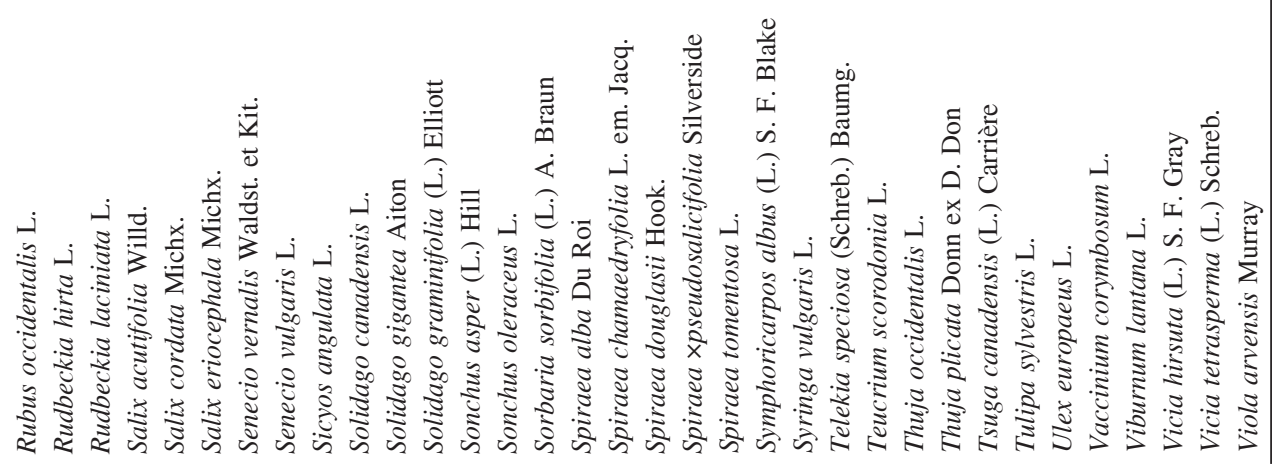


roślin zielnych (46 - bylin i 34 - roślin jednorocznych lub dwuletnich). Większość należy do gromady okrytonasiennych, a tylko 11 do nagonasiennych (wszystkie z klasy iglastych). Gatunki zadomowione w lasach Polski reprezentują 46 rodzin, spośród których najliczniej są reprezentowane Rosaceae (36 gatunków, wyłącznie drzewiastych) i Asteraceae (29 gatunków zielnych), a ze 112 rodzajów do najliczniejszych należą Aster, Lonicera, Rubus i Spiraea (po 5 gatunków z każdego rodzaju).

Pod względem pochodzenia wśród antropofitów w polskich lasach dominują gatunki, które naturalnie występują w Ameryce Północnej (80 taksonów), w Europie lub w Eurazji (59) i w samej Azji (29) oraz odmiany uprawne i mieszańce międzygatunkowe (12) (Ryc. 1). Jedynie 22 gatunki, wyłącznie roślin zielnych, mają w krajowej florze status archeofita, np. Anchusa officinalis, Ballota nigra, Matricaria maritima subsp. inodora lub Senecio vernalis. Spośród gatunków, które na obszarze Polski pojawiły się po XV w., w zbiorowiskach leśnych zadomowionych jest 149 gatunków, w tym wszystkie gatunki drzewiaste. W przypadku pozostałych 9 taksonów, z powodu braku wiarygodnych danych, nie ustalono przynależności do jednej z rozpatrywanych grup, tzn. archeofitów lub kenofitów (Ryc. 2).

Stanowiska roślin obcego pochodzenia, które zadomowiły się w lasach Polski, powstawały w różnym czasie i mają różną genezę, nierzadko związaną z kilkoma niezależnymi od siebie czynnikami takimi, jak introdukcja, zawleczenie czy samorzutna migracja z zewnątrz (Ryc. 3). Najliczniejszą, bo liczącą 78 taksonów grupę zadomowionych przybyszów stanowią gatunki, które najczęściej wnikały do środowiska leśnego spontanicznie, od dawna korzystając z rozmaitych, zazwyczaj antropogenicznych zaburzeń

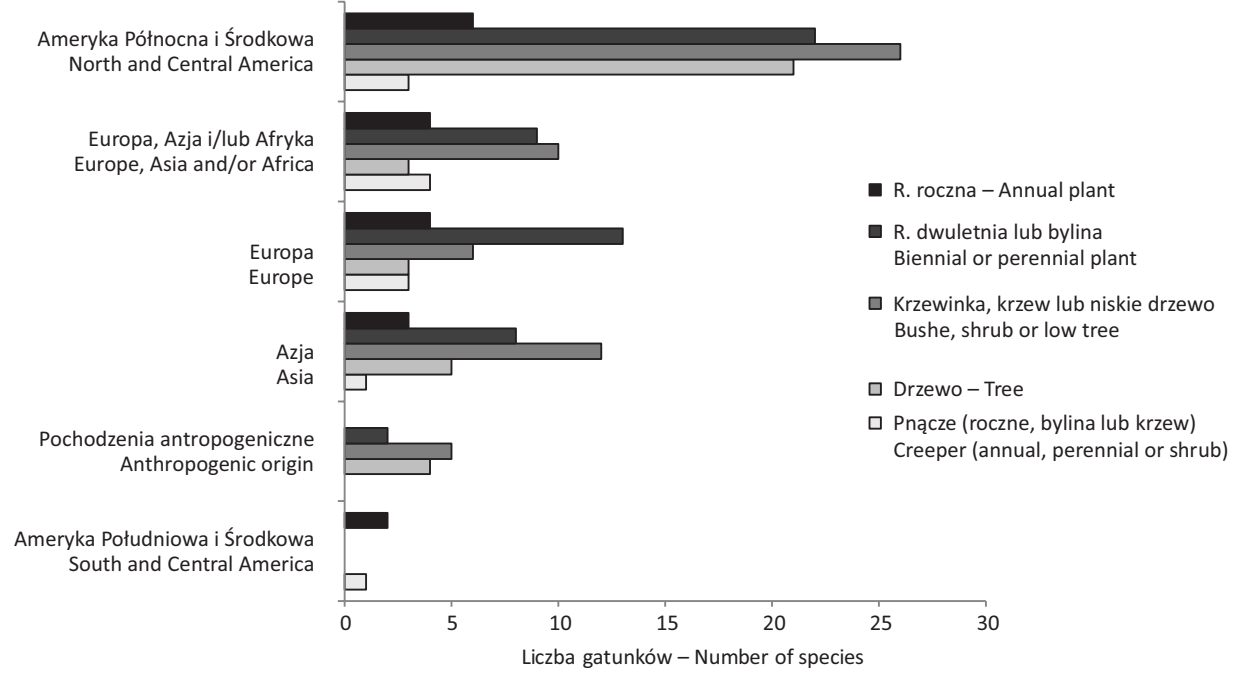

Ryc. 1. Zależność między pochodzeniem i formą życiową rośliny. Obszary pochodzenia: A - Azja, Af - Afryka, Ant - pochodzenie antropogeniczne, E - Europa, CA - Ameryka Środkowa, NA - Ameryka Północna, SA - Ameryka Południowa. Formy życiowe: C - pnącze, A - roślina roczna (terofit), B - roślina dwuletnia, P - bylina, S - krzew, T - drzewo

Fig. 1. Relationship between origin and life form of plant. Origin (native range): A - Asia, Af - Africa, Ant - anthropogenic origin, E - Europe, CA - Central America, NA - North America, SA - South America. Life form: C - climber, $\mathrm{A}$ - annual plant (therophyte), B - biennial plant, $\mathrm{P}$ - perennial, $\mathrm{S}$ - shrub, $\mathrm{T}$ - tree 


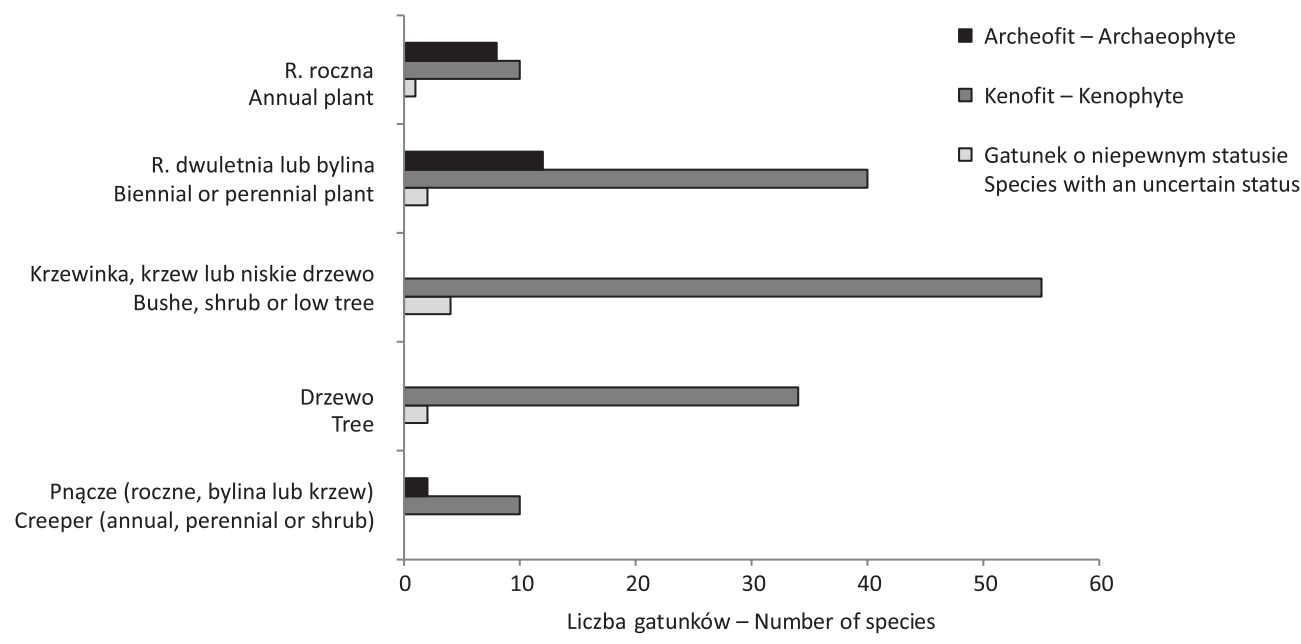

Ryc. 2. Zależność między czasem przybycia i formą życiową rośliny

Fig. 2. Relationship between time of arrival and life form of plant

środowiskowych, sprzyjających rozpowszechnianiu się przedstawicieli flory synantropijnej, zarówno krajowej, jak i obcej. Wśród nich jest 56 gatunków roślin zielnych (27 bylin oraz 29 gatunków jednorocznych i/lub dwuletnich), w większości pospolitych w całym kraju. Drzewa i krzewy z tej grupy, np. Cornus sericea, Acer negundo, Juglans regia, Ribes rubrum, Prunus domestica, $P$. cerasifera, Cerasus vulgaris albo $C$. mahaleb, są przeważnie uciekinierami z upraw - ogrodów, sadów, parków, zadrzewień przydrożnych lub innych, powstałych spontanicznie, stanowisk wtórnych. Niektóre z wymienionych gatunków były

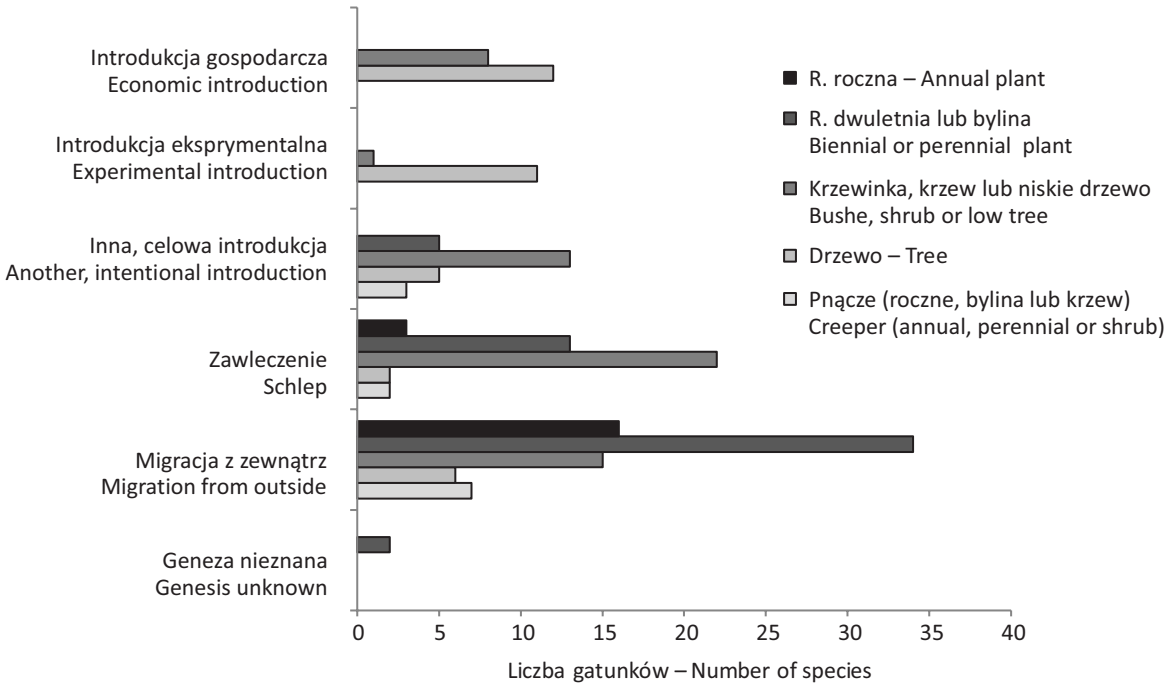

Ryc. 3. Zależność między sposobem przybycia i formą życiową rośliny

Fig. 3. Relationship between pathway of arrival and life form of plant 
też niekiedy sadzone w lasach, lecz zbyt rzadko, by uznać to za główną przyczynę powstawania większości ich leśnych stanowisk.

Druga pod względem liczebności grupa to 42 gatunki, które najczęściej dostawały się do środowiska leśnego wskutek przypadkowego zawleczenia przez człowieka, zwykle przez porzucanie odpadów ogrodowych lub przemieszczanie roślin wraz z podłożem w czasie robót ziemnych. Genezę tego typu można przypisać stanowiskom takich gatunków, jak m.in.: Reynoutria sachalinensis i $R$. japonica, Aster lanceolatus, A. novi-belgii i A. novae-angliae czy Geranium macrorrhizum, a z roślin drzewiastych - Philadelphus sp., Symphoricarpos albus, Spiraea $\times$ pseudosalicifolia i $S$. chamaedryfolia, Rubus laciniatus i $R$. armeniacus, Mahonia aquifolium oraz Rosa glauca i $R$. virginiana. Ponadto niektóre z wymienionych gatunków ozdobnych przenikały do środowiska leśnego w rezultacie rozrostu wegetatywnego z blisko położonych stanowisk uprawy, np. ze znajdujących się w strefie granicy lasu zadrzewień, cmentarzy, szkółek itp.

Około jednej trzeciej taksonów zadomowionych w lasach stanowią rośliny, które zostały do nich wprowadzone $\mathrm{w}$ ramach celowej introdukcji, jaką realizowano w ramach gospodarki leśnej lub/i zaplanowanych prac eksperymentalnych albo okazjonalnie, zazwyczaj z pobudek niezwiązanych bezpośrednio z celami leśnictwa (58 gatunków). Są wśród nich powszechnie znane drzewa i krzewy wprowadzane do lasów ze względów produkcyjnych, biocenotycznych i fitomelioracyjnych, jak: Pseudotsuga menziesii, Quercus rubra, Robinia pseudoacacia, Padus serotina, Larix kaempferi, Pinus strobus, Thuja plicata, Amelanchier spicata i A. lamarckii oraz Sorbaria sorbifolia. Do tej grupy należą także rośliny rzadsze i mniej znane ze stanowisk w naszych lasach, np. Picea sitchensis, Betula lenta, Quercus cerris, Laburnum anagyroides, Castanea sativa, a z gatunków zielnych - Helianthus tuberosus, Lupinus polyphyllus i Asclepias syriaca.

Wśród gatunków objętych celową introdukcją (np. gospodarczą lub eksperymentalną) największy udział mają gatunki pochodzące z Ameryki Północnej (35 gatunków). Ze względu na częstą uprawę w Europie, gatunki północnoamerykańskie stanowią również najliczniejszą grupę wśród roślin, które spontanicznie wniknęły do środowiska leśnego z zewnątrz (24 gatunki) (Ryc. 4).

Do kategorii pospolitych roślin (mających setki i tysiące stanowisk), zadomowionych w lasach obszaru Polski należy 78 gatunków, w tym zaledwie 16 z grupy drzewiastych. Natomiast do najrzadszych (kilkanaście i mniej stanowisk) - 53 gatunki, wśród których są aż 42 gatunki drzew i krzewów. Pozostałe mają kilkadziesiąt stanowisk rozproszonych w Polsce lub skupionych tylko w niektórych regionach.

W przypadku 20\% zadomowionych gatunków duży wzrost liczby stanowisk obserwowany jest w ostatnich dziesięcioleciach. Dotyczy to przede wszystkim roślin zielnych (24 gatunki), a w mniejszym stopniu drzewiastych (11 gatunków, w tym 5 z grupy najpospolitszych i 6 rzadszych w skali Polski, jak: Spiraea tomentosa, Quercus cerris czy Thuja plicata). Większość antropofitów leśnych (135 gatunków) w niewielkim stopniu poszerza swe wtórne zasięgi bądź nie wykracza poza miejsca ich stwierdzenia. Do zanikających elementów obcej flory leśnej należy 7 gatunków, w tym kilka dość częstych, np. Pinus banksiana i Populus ×canadensis oraz rzadko u nas spotkanych, jak Acer saccharum, Pinus peuce czy Ulex europaeus. Wymienione gatunki nie są już wprowadzane do uprawy 


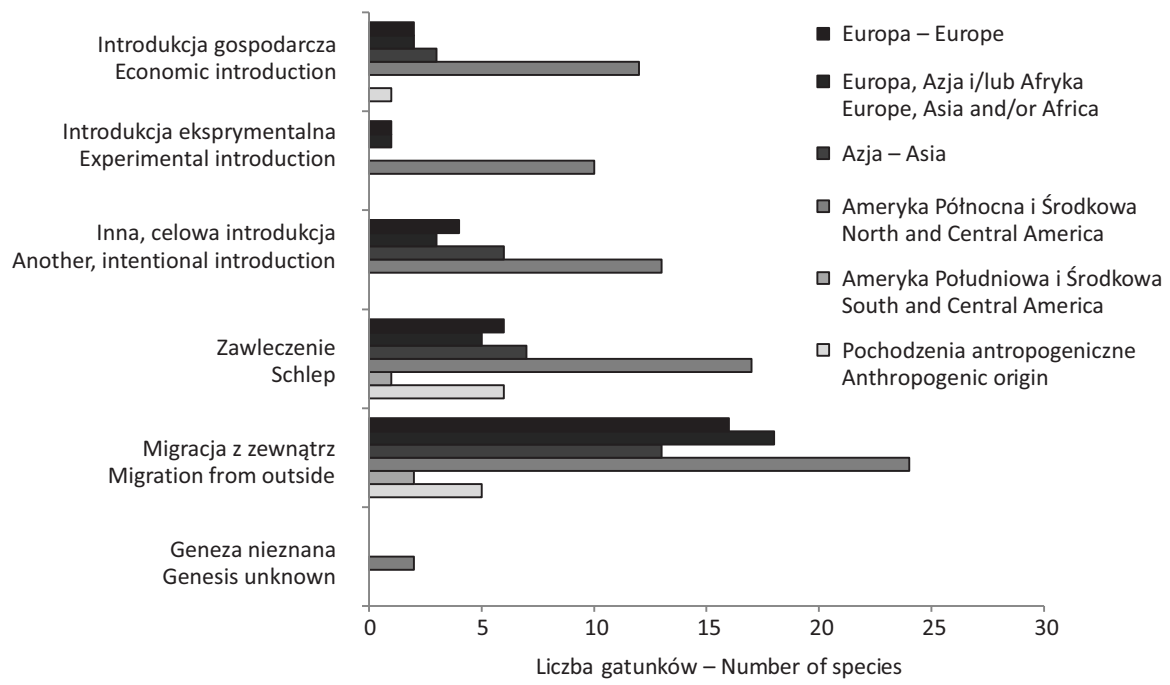

Ryc. 4. Zależność między sposobem przybycia i pochodzeniem

Fig. 4. Relationship between pathway of arrival and origin of plant

w lasach, a na powstałych dawniej stanowiskach nie rozmnażają się i wymierają lub bywają usuwane. O tendencjach dynamicznych pozostałych kilku taksonów nie udało się uzyskać wiarygodnych informacji.

Dane na temat stanowisk większości gatunków obcych zadomowionych w lasach pochodzą z miejsc występowania antropogenicznych zbiorowisk roślinnych, do których należą zniekształcone fitocenozy leśne, o zaburzonej strukturze i składzie florystycznym, a także nieleśne zbiorowiska zrębów, polan, ekotonów, przydroży i sztucznie wytworzonych siedlisk, jak rowy melioracyjne czy nasypy. Poza rzadko występującymi u nas gatunkami obcego pochodzenia i nielicznymi antropofitami charakteryzującymi się wąską skalą ekologiczną, przeważająca część pozostałych taksonów jest zadomowiona w kilku typach zbiorowisk.

W leśnych zbiorowiskach zastępczych, zwykle o charakterze monokultur drzew iglastych założonych na mezotroficznych i eutroficznych siedliskach lasów liściastych, często na gruntach porolnych, zadomowiło się 111, a więc najwięcej gatunków obcych, z których jedynie około 20 wykazuje zdolność do zadomowienia w najlepiej zachowanych fitocenozach lasów naturalnych lub zbliżonych do naturalnych. Można do nich zaliczyć 10 gatunków drzew i krzewów, przy czym takie jak: Padus serotina, Quercus rubra, Pyrus communis, Malus domestica, Acer negundo, Fraxinus pennsylvanica i Amelanchier spicata, należą do pospolitych lub częstych w całym kraju, a inne, jak np. Cornus sericea, Amelanchier lamarckii i Spiraea tomentosa - do rzadszych, lecz w skali lokalnej lub regionalnej znanych z bardzo licznych lub licznych i obfitych stanowisk wtórnych. Z roślin zielnych zdolność do naturalizacji w środowisku najlepiej zachowanych lasów naturalnych ujawniły gatunki szeroko rozpowszechnione w całej Polsce lub w niektórych regionach, np. Solidago gigantea, Digitalis purpurea, Impatiens parviflora i I. glandulifera, Reynoutria $\times$ bohemica i R. japonica, Rudbeckia laciniata, Helianthus tuberosus i Bidens frondosa. 
Do roślin drzewiastych, które osiągnęły etap zadomowienia w leśnych zbiorowiskach zastępczych należy liczna grupa 68 gatunków introdukowanych i zawleczonych do zbiorowisk leśnych oraz wkraczających do nich z upraw znajdujących się poza lasami. Znaczną część z tej grupy gatunków stanowią taksony znane dotychczas z nielicznych stanowisk w lasach, np.: Aronia $\times$ prunifolia, Betula lenta, Tsuga canadensis, Padus virginiana, Quercus cerris, Celastrus orbiculatus, Cotoneaster lucidus i C. divaricatus, Rubus canadensis i R. laciniatus, Castanea sativa, Acer saccharum i A. saccharinum, Alnus rugosa, Juglans nigra, Carya ovata, Ptelea trifoliata, Robinia viscosa, Lonicera caucasica, Picea orientalis i P. sitchensis, Celtis occidentalis i Laburnum anagyroides. Z tej grupy częstsze są m.in. takie gatunki, jak: Pseudotsuga menziesii, Aesculus hippocastanum, Mahonia aquifolium, Juglans regia, Robinia pseudoacacia, Pinus strobus, Prunus cerasifera, Parthenocissus inserta i Prunus mahaleb.

Przedstawicielami grupy roślin zielnych ujawniających zdolność do zadomowienia się w leśnych zbiorowiskach zastępczych są m.in. gatunki nitrofilne, częste w fitocenozach z Robinia pseudoacacia w drzewostanie, jak Ballota nigra i Lamium album bądź wkraczające do zniekształconych łęgów (np. plantacji topolowych) - Echinocystis lobata, Conium maculatum, Echinochloa crus-galli oraz Galinsoga ciliata i G. parviflora, a także nierzadkie w tzw. chojniakach sosnowych, zwłaszcza w krajobrazie rolniczym - Lupinus polyphyllus, Conyza canadensis, Solidago canadensis, Erigeron annuus i Juncus tenuis.

Około jednej trzeciej gatunków obcych nie znajduje odpowiednich warunków do wytwarzania samoutrzymujących się populacji wtórnych w leśnych zbiorowiskach naturalnych i zastępczych. Należą do nich drzewa i krzewy zadomowione na obrzeżach lasów, na przydrożach, polanach, w miejscach prześwietlonych, często w pobliżu pozostałości dawnych zabudowań. Są to np. Lycium barbarum, Physocarpus opulifolius, Morus alba, Prunus domestica, Rhus typhina, Syringa vulgaris, Rosa multiflora, R. rugosa i $R$. virginiana, Spiraea douglasii i S. pseudosalicifolia, Salix acutifolia, Rubus armeniacus lub Viburnum lantana. Rośliny zielne zaliczane do grupy antropofitów zadomowionych jedynie w zbiorowiskach nieleśnych, na obszarach leśnych są reprezentowane głównie przez gatunki powszechnie spotykane jedynie w zbiorowiskach segetalnych i ruderalnych - najczęściej na poletkach łowieckich oraz na obrzeżach lasów, zwłaszcza w bliskim sąsiedztwie terenów rolnych, osadniczych i przemysłowych.

Oceniając omawianą grupę gatunków obcego pochodzenia pod względem oddziaływania na rodzime składniki flory i roślinność leśną, można stwierdzić, że najsilniejszy, edyfikacyjny wpływ, tożsamy z kategorią transformers według RicHARDSONA i in. (2000), wywierają te gatunki, których spontanicznie powstałe populacje wtórne są zdolne do opanowywania zbiorowisk i powodują zasadnicze zmiany w ich strukturze i funkcjonowaniu. Najłatwiej dostrzegalnym i najbardziej spektakularnym przejawem skutków rozwoju takich populacji jest szybkie lub stopniowe wypełnianie przez nie dużych przestrzeni i względnie długotrwała dominacja nad populacjami innych gatunków. Zbiorowiska leśne w takich sytuacjach najczęściej ulegają przeobrażeniom na skutek ekspansji obcych drzew i krzewów, bezpośrednio przyczyniającej się do przekształcenia składu i struktury drzewostanu oraz warstwy podszytu i podrostu, a pośrednio - do zmian w runie. Ze 113 gatunków zadomowionych w zbiorowiskach leśnych, 10 wykazuje edyfikacyjny stosunek do rodzimych 
komponentów zbiorowisk (Ryc. 5). Do gatunków najpospolitszych i powszechnie znanych $\mathrm{z}$ tej grupy należą drzewa: Padus serotina, Robinia pseudoacacia oraz Acer negundo. W kilku regionach Polski zdolność do spontanicznego tworzenia wtórnych drzewostanów przejawia także Thuja plicata, a bujną i gęstą warstwę krzewów w fitocenozach leśnych miejscami tworzą Aronia ×prunifolia, Cornus sericea, Cotoneaster lucidus, Spiraea tomentosa oraz Amelanchier spicata i A. lamarckii. Możliwość tworzenia obfitych populacji wtórnych i w związku z tym zdolności do redukcyjnego oddziaływania na autochtoniczne składniki zbiorowisk leśnych, jednak bez zaburzania ich zasadniczej struktury i funkcji, ujawniają 22 gatunki. Wśród drzew są to: Quercus rubra, Fraxinus pennsylvanica i Robinia viscosa, z pnączy - Celastrus orbiculatus, Clematis vitalba i Parthenocissus inserta, z krzewów - Lonicera tatarica, Symphoricarpos albus i Laburnum anagyroides, a spośród roślin zielnych - Heracleum sosnowskyi, Impatiens parviflora i I. glandulifera, trzy wymienione wcześniej taksony z rodzaju Reynoutria, Rudbeckia laciniata, Helianthus tuberosus, Solidago canadensis, S. gigantea, S. graminifolia oraz Bidens frondosa. Większość - 58 gatunków drzewiastych i 23 gatunki zielne, spośród 113 zadomowionych w zbiorowiskach leśnych, należy do roślin, których oddziaływanie na rodzimą florę, jak dotąd, polega jedynie na jej wzbogacaniu lub kompensacji. W związku z tym można stwierdzić, że około $10 \%$ gatunków zadomowionych w środowisku leśnym wywiera najbardziej istotny wpływ na fitocenozy leśne, powodując ich zniekształcanie.

Biorąc pod uwagę wpływ gatunków obcych na gospodarkę leśną należy stwierdzić, że największe utrudnienia dotyczą głównie zabiegów prowadzonych przy odnawianiu lasu. Trudności te stwarzają przede wszystkim gatunki roślin drzewiastych, które m.in. ze względu na wieloletnią trwałość, osiągane rozmiary i zajmowaną przestrzeń, z reguły mają silniejsze oddziaływanie na rozwój upraw leśnych niż rośliny zielne. Oprócz pospolitych - Padus serotina i Robinia pseudoacacia, do tej grupy roślin można zaliczyć jeszcze

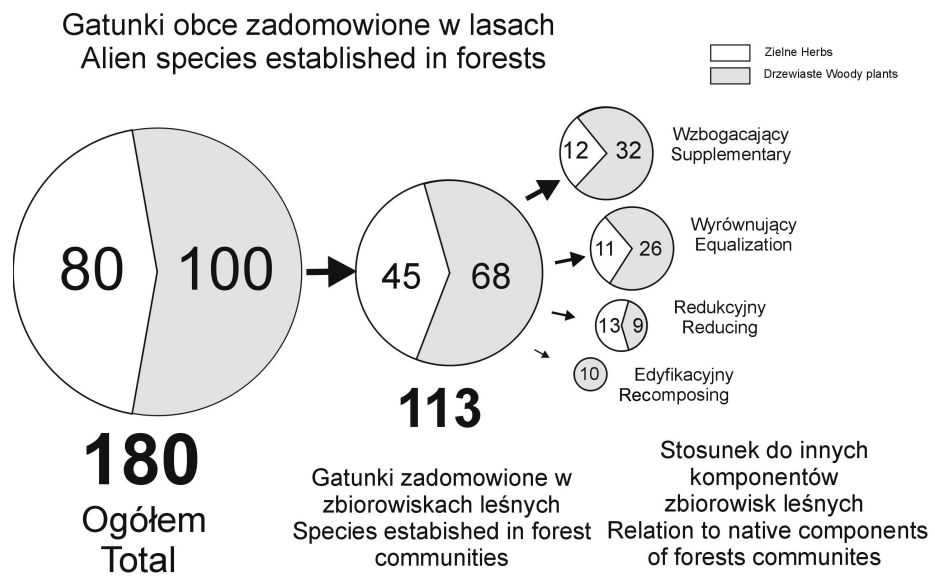

Ryc. 5. Liczby gatunków zadomowionych w lasach Polski

Fig. 5. Numbers of species established in Polish forests 
7 gatunków, które były lub są zwalczane na niektórych stanowiskach w ramach zabiegów przygotowania gleby pod uprawy i pielęgnacji upraw leśnych; są to: Quercus rubra, Cornus sericea, Acer negundo, Amelanchier spicata i A. lamarckii, Cotoneaster lucidus i Spiraea tomentosa. Do kilkunastu gatunków, które lokalnie mogą być uznawane za uciążliwe dla gospodarki leśnej i w najbliższej przyszłości stać się przedmiotem zwalczania, należą m.in: Aronia $\times$ prunifolia, Parthenocissus inserta, Celastrus orbiculatus, Fraxinus pennsylvanica, Robinia viscosa i Rosa rugosa, a z roślin zielnych - wspomniane wcześniej gatunki z rodzajów Solidago, Reynoutria oraz Rudbeckia laciniata. W stosunku do innych obcych gatunków drzew i krzewów oraz roślin zielnych są także podejmowane działania zmierzające do ich eliminacji, jednak odbywają się one na podobnych zasadach, jakie przyjmuje się w ochronie upraw leśnych przed niepożądanymi roślinami (,chwastami”), zarówno obcymi, jak i rodzimymi.

\section{DYSKUSJA}

Mimo że liczba wszystkich gatunków obcego pochodzenia w lasach obszaru Polski jest trudna do oszacowania, to biorąc pod uwagę fakt stwierdzenia pośród nich ponad 200 obcych taksonów tylko drzew i krzewów (DANIELEWICZ \& WiATROwSKA 2014), należy założyć, iż jest ona znacznie większa od liczby taksonów trwale zadomowionych. Środowisko leśne, w którym 180 gatunków obcych stało się trwałymi składnikami flory naczyniowej, stanowi więc swego rodzaju barierę dla naturalizacji wielu taksonów, które w innych warunkach osiągają u nas ten etap adaptacji, o czym świadczy liczba 527 zadomowionych archeofitów i kenofitów wymienionych na krajowej liście roślin obcego pochodzenia (TOKARSKA-GUZIK i in. 2012). Porównując udział różnych form życiowych reprezentowanych przez gatunki obce, uwagę zwraca przewaga drzew i krzewów we florze zbiorowisk leśnych $(55,5 \%)$, podczas gdy we florze ogólnokrajowej dominują obce gatunki roślin zielnych (75,6\%), co jednocześnie rzutuje na udział grup taksonomicznych. We florze naczyniowej Polski rodziny najbogatsze $w$ gatunki to jednocześnie grupy taksonomiczne obejmujące dużą liczbę zadomowionych antropofitów zielnych: z rodziny Asteraceae - 70 gatunków, Brassicaceae - 39, Poaceae - 37. Natomiast we florze zbiorowisk leśnych najbogatsza w gatunki jest rodzina Rosaceae (36), reprezentowana w lasach tylko przez obce rośliny drzewiaste, głównie krzewy. Jest to związane $\mathrm{z}$ większym zainteresowaniem uprawą obcych drzew i krzewów niż roślin zielnych na terenach leśnych (DANIELEWICZ \& WiatrowsKA 2012, 2015) oraz z tym, że w ich pobliżu znajdują się sady, parki i ogrody, skąd spontanicznie lub przez zawleczenie gatunki z rodziny Rosaceae przedostawały się do lasów. Sama introdukcja, gospodarcza i eksperymentalna, obcych drzew i krzewów do środowiska leśnego przyczyniła się do zadomowienia mniejszej liczby gatunków (KRóL 1988, 2000), chociaż w przypadku niektórych z nich, takich jak Padus serotina, Quercus rubra czy Robinia pseudoacacia, które były uprawiane na szeroką skalę, doszło do ich ekspansji w bardzo wielu miejscach w Polsce, podobnie jak w innych krajach europejskich (RICHARDSON \& REJMÁNEK 2011; GAZDA 2013; WOZIWODA i in. 2014). Gdyby w leśnictwie na podobną skalę wykorzystywano inne gatunki, wprowadzane stosunkowo rzadko, np. Aronia $\times$ prunifolia, Cotoneaster lucidus czy Amelanchier sp., problem z ich ekspansją byłby dostrzegany także 
w całym kraju, co wynika m.in. z ich zdolności do rozprzestrzeniania się w środowisku leśnym, obserwowanej do tej pory na stosunkowo nielicznych stanowiskach (DANIELEWICZ \& Maliński 1996, 2004; Purcel 2009, 2011; CelKa \& Szkudlarz 2010).

Analiza listy roślin obcych zadomowionych w zbiorowiskach leśnych o różnym stopniu przekształcenia ogólnie potwierdza wyrażaną w literaturze opinię, że gatunki nierodzime mają istotnie mniejszą możliwość efektywnego zasiedlania fitocenoz charakteryzujących się wysokim stopniem naturalności (LONSDALE 1999; PYšEK i in. 2002; MARTIN i in. 2009), chociaż typy lasów naturalnych i zbliżonych do naturalnych różnią się podatnością na wnikanie antropofitów. $Z$ reguły lasy nizinne środkowej Europy są penetrowane przez więcej gatunków obcych niż lasy górskie (GAZDA 2013), a ich liczba w stosunku do gatunków rodzimych jest większa w zbiorowiskach na siedliskach żyznych i wilgotnych, zwłaszcza aluwialnych, niż w zbiorowiskach siedlisk suchszych i mniej zasobnych (KALusovÁ i in. 2014).

Zgodnie z powszechnie przyjmowanymi w literaturze kryteriami klasyfikacji obcych roślin (RICHARDSON i in. 2000) spośród 113 antropofitów zadomowionych w zbiorowiskach leśnych, do kategorii transformers można zaliczyć 10 gatunków wykazujących zdolność do przekształcania struktury fitocenoz, natomiast do inwazyjnych -22 gatunki o redukcyjnym stosunku do rodzimych komponentów zbiorowisk, przy czym większość gatunków z tej grupy jest uważana u nas za gatunki inwazyjne lokalnie (TOKARSKA-GUZIK i in. 2012).

Skuteczność zwalczania ekspansywnych roślin obcego pochodzenia w lasach i powstrzymywania ich spontanicznego rozprzestrzeniania się, zwłaszcza na obszarach ważnych dla zachowania naturalnej różnorodności biologicznej, w skali lokalnej czy pojedynczych obiektów leśnych, wydaje się satysfakcjonująca (DAJdOK \& PAWLACZYK 2009; OtRĘBA \& MichalsKa-HejDUK 2014; OBIDZIŃSKI i in. 2016), jednak są gatunki, których liczba stanowisk na terenie kraju ciągle wzrasta, a sytuacja, także z punktu widzenia gospodarki leśnej, jest daleka od zadowalającej.

\section{WNIOSKI}

(1) Liczba gatunków obcych, które można uznać za w pełni zadomowione w zbiorowiskach leśnych obszaru Polski jest znacznie mniejsza od liczby wszystkich antropofitów stwierdzonych do tej pory na obszarze naszego kraju. Jest to $\mathrm{z}$ jednej strony związane z wymogami siedliskowymi samych gatunków, a z drugiej wiąże się ze specyfiką środowiska leśnego, które mimo różnych przemian nadal charakteryzuje się wyższym stopniem naturalności w porównaniu z innymi typami środowisk, które są bardziej przekształcone i „bogatsze" w obce składniki flory naczyniowej.

(2) Celowa introdukcja obcych roślin do lasów przyczyniła się do zadomowienia przede wszystkim form drzewiastych, w tym kilku gatunków na obszarze całego kraju. Duża część antropofitów, szczególnie roślin zielnych, przedostała się do środowiska leśnego spontanicznie lub przez zawleczenie z miejsc położonych poza nim, niezależnie od ich introdukcji.

(3) Nie wszystkie gatunki obce zadomowione na terenach leśnych wykazują zdolność do penetracji zbiorowisk leśnych, a niewiele spośród nich do tworzenia samoutrzymujących się populacji w najlepiej zachowanych fitocenozach naturalnych i zbliżonych do naturalnych. 
Około $20 \%$ antropofitów spotykanych w lasach ma wyraźny, negatywny wpływ na skład i strukturę fitocenoz leśnych.

(4) Najwięcej obcych gatunków przejawia zdolność do zadomowienia w leśnych zbiorowiskach zastępczych, zwłaszcza z drzewostanem sosnowym na siedliskach lasów liściastych i na żyznych gruntach porolnych, które ze względu na zakłócone warunki środowiska są bardziej podatne na wnikanie antropofitów niż stabilniejsze zbiorowiska naturalne.

\section{LITERATURA}

Adamowski W., Dvorak L. \& Ramanjuk I. 2002. Atlas of alien woody species of the Białowieża Primaeval Forest. - Phytocoenosis (N.S.) Supplementum Cartographiae Geobotanicae 14: 1-304.

Bellon S., TumiŁowicz J. \& Król S. 1977. Obce gatunki drzew w gospodarstwie leśnym. s. 266. Państwowe Wydawnictwo Rolnicze i Leśne, Warszawa.

CElKa Z. \& SZKudLaRZ P. 2010. Spontaneous occurrence and dispersion of Aronia xprunifolia (Marshall) Rehder (Rosaceae) in Poland on the example of the "Bagna" bog complex near Chlebowo (western Poland). - Acta Societatis Botanicorum Poloniae 79(1): 37-42.

ChYlarecki H. 1963. Badania nad przeorzechami (Carya Nutt.) uprawianymi w Polsce w warunkach środowiska leśnego. - Arboretum Kórnickie 8: 29-54.

ChYlarecki H. 2004. Daglezja w lasach Polski. Potencjał produkcyjny, wymagania ekologiczne, biologia. s. 137. Bogucki Wydawnictwo Naukowe, Poznań.

DAJDOK Z. \& PAWLACZYK P. (red.). 2009. Inwazyjne gatunki roślin naczyniowych ekosystemów mokradłowych Polski. s. 167. Wydawnictwo Klubu Przyrodników, Świebodzin.

Dajdok Z., Nowak A., Danielewicz W., Kujawa-PawlaczyK J. \& Bena W. 2011. NOBANIS - Invasive Alien Species Fact Sheet - Spiraea tomentosa. - Online Database of the North European and Baltic Network on Invasive Alien Species - NOBANIS www.nobanis.org. ((dostęp: 05.02.2017).

DANiElewicz W. \& Maliński T. 1996. Rodzaj Amelanchier Med. - świdośliwa w Wielkopolskim Parku Narodowym. - Prace Wielkopolskiego Parku Narodowego, Morena 4: 19-35.

DANIELEWICZ W. \& MALIŃSKi T. 1997. Drzewa i krzewy obcego pochodzenia w lasach Wielkopolskiego Parku Narodowego. - Rocznik Dendrologiczny 45: 65-81.

DANiElewicz W. \& Maliński T. 2003. Alien tree and shrubs species in Poland regenerating by self-sowing. - Rocznik Dendrologiczny 51: 205-236.

DANIElewicz W. \& MalińsKi T. 2004. Naturalization of Cotoneaster lucidus Schltdl. in Wielkopolski National Park. - Rocznik Dendrologiczny 52: 197-214.

DANiElewicz W. \& Wiatrowska B. 2012. Motywy, okoliczności i środowiskowe konsekwencje wprowadzania obcych gatunków drzew i krzewów do lasów. - Studia i Materiały Centrum Edukacji Przyrodniczo-Leśnej, Rogów 33(4): 26-43.

Danielewicz W. \& Wiatrowska B. 2013. Prunus virginiana L. (Rosaceae) on synanthropic sites in Poland. - Acta Scientiarum Polonorum Silvarum Colendarum Ratio et Industria 12(4): 5-22.

DANIElewicz W. \& Wiatrowska B. 2014. Inwazyjne gatunki drzew i krzewów w lasach Polski. - Peckiana 9: $59-67$.

Danielewicz W. \& Wiatrowska B. 2015. Różnorodność i przemiany dendroflory Polski. - Studia i Materiały Centrum Edukacji Przyrodniczo-Leśnej, Rogów 42(1): 13-26.

Danielewicz W., Kiciński P. \& Antosz Ł. 2014. Turkey oak (Quercus cerris L.) in Polish forests. - Acta Scientiarum Polonorum Silvarum Colendarum Ratio et Industria Lignaria 13(2): 5-22. 
Danihelka J., Chrtek JR. J. \& Kaplan Z. 2012. Checklist of vascular plants of the Czech Republic. - Preslia 84: 647-811.

FALIŃSKI J. B. 1968. Stadia neofityzmu i stosunek neofitów do innych komponentów zbiorowiska. Materiały Zakładu Fitosocjologii Stosowanej Uniwersytetu Warszawskiego 25: 15-31.

FALIŃSKi J. B. 2004. Inwazje w świecie roślin: mechanizmy, zagrożenia, projekt badań. - Phytocoenosis N.S. 16, Seminarium Geobotanicum 10: 1-32.

GAZDA A. 2013. Występowanie drzew obcego pochodzenia na tle zróżnicowania lasów Polski południowej. - Zeszyty Naukowe Uniwersytetu Rolniczego w Krakowie 512, Rozprawy 389: 1-118.

GaZDA A. \& Augustynowicz P. 2012. Obce gatunki drzew w polskich lasach gospodarczych. Co wiemy o puli i rozmieszczeniu wybranych taksonów? - Studia i Materiały Centrum Edukacji PrzyrodniczoLeśnej, Rogów 33(4): 53-61.

KalusovÁ V. Chytry V., Chytrý M., Peet R. K. \& Wentworth T. R. 2014. Alien species pool influences the level of habitat invasion in intercontinental exchange of alien plants. - Global Ecology and Biogeography 23: 1366-1375.

KoRNAŚ J. 1981. Oddziaływanie człowieka na florę: mechanizmy i konsekwencje. - Wiadomości Botaniczne 25(3): 165-182.

KRÓL S. 1988. Synantropizacja fitocenoz leśnych przez introdukcję obcych gatunków drzew. - Wiadomości Botaniczne 32(2): 115-124.

KRÓL S. 2000. Problemy synatropizacji lasów a penetracja antropofitów dendroflory. - W: T. BoJARCZUK \& W. BugaŁa (red.), Bioróżnorodność a synantropizacja zbiorowisk leśnych, s. 15-31. Materiały Zjazdu Sekcji Dendrologicznej PTB - referaty, doniesienia, postery. Wirty.

Lambdon P. W., Pyšek P., Basnou C., Hejda M., Arianoutsou M., Jarošík V., Pergl J., Winter mM., Anastasiu P., Andriopoulos P., Bazos I., Brundu G., Celesti-Grapow L., Chassot P., Delipietrou P., Josefsson M., Kark S., Klotz S., Kokkoris Y., Kưhn I., Marachante H., Perglová I., Pino J., Vilà M., Zikos A., Roy D. \& Hulme P. E. 2008. Alien flora of Europe: species diversity, temporal trends, geographical patterns and research needs. - Preslia 80: 101-149.

LonsDale W. M. 1999. Global patterns of plant invasions and concept of invasibility. - Ecology 80: $1522-1536$.

Martin P. H., Canham C. D. \& Marks P. L. 2009. Why forests appear resistant to exotic plant invasions: intentional introductions stand, and the role of shade tolerance. - Frontiers in Ecology and Environments 7: 142-149.

Medwecká J., Kliment J., Májeková J., Halada L., Zaliberová M., Gojdičová E., Feráková V. \& JAROLÍMEK I 2012. Inventory of alien flora of Slovakia. - Preslia 84: 257-309.

MILEWSKI W. (red.). 2018. Lasy w Polsce 2018. s. 29. Centrum Informacyjne Lasów Państwowych, Warszawa.

Mirek Z., Pięroś-Mirkowa H., Zając A. \& Zając M. 1995. Vascular plants of Poland. A checklist. - Polish Botanical Studies, Guidebook Series 15: 1-303.

Mirek Z., PięKoś-Mirkowa H., Zając A. \& ZająC M. 2002. Flowering plants and pteridophytes of Poland. A checklist. - W: Z. MireK (red.), Biodiversity of Poland. 1, s. 442. W. Szafer Institute of Botany, Polish Academy of Sciences, Kraków.

OBidziński A., KołACZKowsKa E. \& OtRĘBA A. (red.). 2016. Metody zwalczania obcych gatunków roślin występujących na terenie Puszczy Kampinoskiej. s. 132. Kampinoski Park Narodowy, Izabelin.

Obidziński A., PAluszek D., DŁugoŁęCKi W. \& Kuberski Ł. 2003. Ekspansja obcych gatunków roślin drzewiastych z Arboretum SGGW w Rogowie. - Rocznik Dendrologiczny 51: 89-97.

OtręBA A. \& Michalska-Hejduk D. (red.). 2014. Inwazyjne gatunki roślin w Kampinoskim Parku Narodowym i w jego sąsiedztwie. s. 120. Kampinoski Park Narodowy, Izabelin. 
Piotrowska H., Żukowski W. \& JACKOwiak B. 1997. Rośliny naczyniowe Słowińskiego Parku Narodowego. Prace Zakładu Taksonomii Uniwersytet Adama Mickiewicza 6. s. 2016. Bogucki Wydawnictwo Naukowe, Poznań.

PIóRECKI J. 2013. Rośliny naczyniowe dzikie, zadomowione i uprawowe na Pogórzu Przemyskim. s. 456. Arboretum i Zakład Fizjografii, Bolestraszyce.

Purcel A. 2009. Obce gatunki drzew i krzewów w Wielkopolskim Parku Narodowym - ich występowanie i rola w biocenozach parku. - Prace Wielkopolskiego Parku Narodowego, Morena 14: 35-191.

PURCEL A. 2011. Zdecydowane nie! obcym gatunkom ekspansywnych drzew i krzewów w terenach zieleni komponowanej i otwartym krajobrazie Polski. - W: M. E. DROzDEK (red.), Rośliny do zadań specjalnych, s. 423-438. Oficyna Wydawnicza Państwowa Wyższa Szkoła Zawodowa w Nysie, Sulechów - Kalsk.

PYŠEK P., JARošíK V. \& KUČERA T. 2002. Patterns of invasion in temperate reserves. - Biological Conservation 104: 13-24.

Pyšek P., Richardson D. M., Rejmanek M., Webster G. L., Williamson M. \& Kirschner J. 2004. Alien plants in checklists and floras: towards better communication between taxonomists and ecologists. - Taxon 53(1): 31-143.

Pyšek P., Danihelka J., Sádlo J., Chrtek JR. J., Chytrý M., Jarošík V., Kaplan Z., Krahulec F., Moravcová L., Pergl J., Štajerová K. \& TichÝ L. 2012. Catalogue of alien plants of Czech Republic. Ed 2: checklist update, taxonomic diversity and invasion patterns. - Preslia 84: 155-255.

Richardson D. M. \& RejMÁneK M. 2011. Trees and shrubs as invasive alien species - a global review. - Diversity and Distribution 17(5): 788-809.

Richardson D. M., Pyšek P., Rejmánek M., Barbour M. G., Panetta F.D. \& West C. J. 2000. Naturalization and invasion of alien plants: concepts and definitions. - Diversity and Distribution 69(2): 93-107.

SUdNIK-WóJCIKOWSKA B. \& KoźNIEWSKA B. 1988. Słownik z zakresu synatropizacji szaty roślinnej. s. 93. Wydawnictwa Uniwersytetu Warszawskiego, Warszawa.

SzULCZEWSki J.W. 1963. Obcy element w roślinności Wielkopolskiego Parku Narodowego. - Prace Monograficzne nad Przyrodą Wielkopolski Park Narodowy pod Poznaniem 4(2): 1-24.

TOKARSKA-GuZIK B. 2005. The establishment and spread of alien plant species (kenophytes) in the flora of Poland. s. 2016. Wydawnictwo Uniwersytetu Śląskiego, Katowice.

ToKarska-GuZiK B., Dajdok Z., Zając M., ZająC A., UrbisZ A., Danielewicz W. \& HoŁdyŃski C. 2012. Rośliny obcego pochodzenia w Polsce ze szczególnym uwzględnieniem gatunków inwazyjnych. s. 196. Generalna Dyrekcja Ochrony Środowiska, Warszawa.

Wiatrowska B. \& Danielewicz W. 2016. Środowiskowe uwarunkowania inwazji tawuły kutnerowatej (Spiraea tomentosa L.) w Borach Dolnośląskich. - Sylwan 60(8): 696-704.

Woziwoda B., Potocki M., Sagan J., Zasada M., Tomusiak R. \& Wilczyński S. 2014. Commercial forestry as a vector of alien tree species - the case of Quercus rubra L. Introduction in Poland. - Baltic Forestry 20(1): 131-141.

ZAJĄC A. \& ZAJĄC M. (red.). 2001. Atlas rozmieszczenia roślin naczyniowych Polski. s. xii + 714. Nakładem Pracowni Chorologii Komputerowej Instytutu Botaniki Uniwersytetu Jagiellońskiego, Kraków.

ZAJĄC M. \& ZAJĄC A. 2003. Różnorodność gatunkowa - rośliny naczyniowe i inne. - W: R. ANDRZEJEWSKi \& A. WeIGLE (red.). Różnorodność biologiczna Polski, s. 67-91. Narodowa Fundacja Ochrony Środowiska, Warszawa.

Zarzycki K., Trzcińska-TaciK H., Różański W., Szeląg Z., WoŁek J. \& KorZeniak U. 2002. Ekologiczne liczby wskaźnikowe roślin naczyniowych Polski. s. 183. W. Szafer Institute of Botany, Polish Academy of Sciences, Kraków. 
Zieliński J. 1987. Rodzaj Rosa L. - W: A. JASIEwicZ (red.), Flora Polski. Rośliny naczyniowe. 5, s. 49. Państwowe Wydawnictwo Naukowe, Warszawa.

ZielińSKi J. 2004. The genus Rubus (Rosaceae) in Poland. - Polish Botanical Studies 16: 1-300.

Żunowski W., Latowski K., Jackowiak B. \& Chmiel J. 1995. Rośliny naczyniowe Wielkopolskiego Parku Narodowego. - Prace Zakładu Taksonomii Uniwersytetu Adama Mickiewicza w Poznaniu 4: 1-229. Bogucki Wydawnictwo Naukowe, Poznań.

\section{SUMMARY}

The vascular flora of Poland consists of approximately 2500 native and 500 alien species (anthropophytes, alien synanthropic species) that are permanently established, that is, able to create self-sustaining secondary populations. Despite human-caused transformations, forest communities show a relatively high degree of habitat and vegetation naturalness, which makes them an important and interesting subject for research on alien species invasion.

The aim of the study was to compile and present data on the species composition and diversity of the alien flora of forests in Poland. Based on our own materials and literature data, we present a list of vascular plants that can be classified as naturalized in the forest environment according to the criteria adopted in the European literature. The list includes 180 taxa -100 species of woody plants and 80 species of herbaceous plants - belonging to 112 genera in 48 families (Tab. 1). The most numerous are the Rosaceae ( 35 species) and Asteraceae (29) families. Most of these species originate from North America (80 taxa), Asia (29) and Europe (28), while others have wider ranges or are known only from cultivation (Fig. 1). Only 22 species of herbaceous plants have archeophyte status, 149 species are kenophytes, and the status of 9 species is unclear (Fig. 2). Most of the established species (78 species) spontaneously penetrate forest environments from non-forest sites. The second group consists of 42 species that most often enter the forest environment due to accidental displacement by humans (Fig. 3). Approximately a third of the species naturalized in forest communities are plants intentionally introduced into forests. Among the forest anthropophytes, 71 are common; only 16 of these are woody plants. Fifty-three species are very rare, including 42 trees and shrubs. About $20 \%$ of the established plants ( 24 herbaceous and 11 woody species) show a significant increase in the number of stands. Among the intentionally introduced species (e.g. economic or experimental), species originating from North America (35 species) have the largest share. They also constitute the most numerous group among plants that spontaneously penetrated the forest environment from elsewhere (24 species) (Fig. 4). Of 113 species naturalized in forest communities (natural and secondary), 20 taxa were recorded in well-preserved plant communities. The list includes such trees and shrubs as Acer negundo, Amelanchier lamarckii, A. spicata, Cornus sericea, Fraxinus excelsior, Padus serotina and Spiraea tomentosa, and herbaceous plants including the very common Impatiens parviflora, Bidens frondosa, Impatiens glandulifera, Reynoutria sachalinensis, Rudbeckia laciniata and Solidago gigantea (Fig. 5).

Ten woody plant species have shown the ability to control and transform forest communities, including some that are common throughout Poland (Padus serotina, Robinia pseudoacacia, Acer negundo) and species known from smaller stands (Amelanchier spicata, A. lamarckii, Aronia $\times$ prunifolia, Cornus sericea, Cotoneaster lucidus, Spiraea tomentosa, Thuja plicata). Twenty-two species (9 woody and 13 herbaceous plants) can be classified as anthropophytes affecting the native components of the communities, and 81 species ( 23 trees and 58 herbaceous plants) are plants that have so far compensated or enriched the floristic composition of forest communities.

Wptynęto: 03.12.2019 r.; przyjęto do druku: 20.04.2020 r. 